\title{
THREATS TO THE FINANCIAL SECURITY OF THE NATIONAL ECONOMIES IN CENTRAL ASIA COUNTRIES IN TIMES OF FINANCIAL CRISIS
}

\author{
Nurymova Saule, \\ Yessentay Aigerim,
}

PhD doctoral students of the Institute of Economics of the Committee of Science of the Ministry of Education and Science of the Republic of Kazakhstan,

Kazakhstan, Almaty

DOI: https://doi.org/10.31435/rsglobal_ijite/30112018/6214

\section{ARTICLE INFO}

Received 12 September 2018 Accepted 17 November 2018

Published 30 November 2018

\section{KEYWORDS}

financial security, national economies, Central Asia, global trends, development. \begin{abstract}
The most important element of economic security in modern conditions is financial safety. In modern conditions the impact of geofinances, the world's financial systems on the individual state moves to a qualitatively new level. According to the dominant position occupied by a financial component in today's economy, the authors can characterize the last one as an economy controlled by the basis of their financial way, through financial mechanisms, using financial leverage, financial incentives and fiscal purposes. In this article, financial security is considered by the example of developing countries - members of the Shanghai Cooperation Organization in Kazakhstan, Russia and China.
\end{abstract}

Citation: Nurymova Saule, Yessentay Aigerim. (2018) Threats to the Financial Security of the National Economies in Central Asia Countries in Times of Financial Crisis. International Journal of Innovative Technologies in Economy. 8(20). doi: 10.31435/rsglobal_ijite/30112018/6214

Copyright: () 2018 Nurymova Saule, Yessentay Aigerim. This is an open-access article distributed under the terms of the Creative Commons Attribution License (CC BY). The use, distribution or reproduction in other forums is permitted, provided the original author(s) or licensor are credited and that the original publication in this journal is cited, in accordance with accepted academic practice. No use, distribution or reproduction is permitted which does not comply with these terms.

Introduction. The Shanghai Cooperation Organization (SCO) - a regional international organization founded in 2001 by the leaders of China, Russia, Kazakhstan, Tajikistan, Kyrgyzstan and Uzbekistan. Except of Uzbekistan, the other countries were members of the "Shanghai Five", based as a result of the signing in 1996-1997 between Kazakhstan, Kyrgyzstan, China, Russia, Tajikistan agreements on the confidence-building in the military sphere and mutual reduction of armed forces in the border area. After switching on Uzbekistan in 2001, the organization was renamed by the participants.

One of the features of the SCO lies in the fact that it is in respect of the status is neither a military bloc like NATO, nor an open regular meeting of the security, like ASEAN, ARF, occupying an intermediate position. The main objectives of the organization are to strengthen security and stability in the vast territory that unites the States-members to combat terrorism, separatism, extremism, drug trafficking, economic cooperation, energy partnership, scientific and cultural cooperation.

No country is immune from the risks associated with the instability of the financial system. Therefore, financial instability can be defined as such problems in the financial system of the country that have a significant negative impact on economic activity.

Practically, there's no aspect of the national security of the country that wouldn't directly dependent on the level of its financial security. At the same time, the level of the financial security largely depends on the level of other aspects of national security. Consideration of the relationships 
and interdependencies between the various aspects of national security allows finding measures to prevent or overcome threats to the country's national interests.

The dependence of all aspects of the national security of the country on its financial security is very simple at the first glance: lack of funds often leads to underfunding the most pressing needs in the various sectors of the economy and poses a threat to national security. However, this seemingly simple, the most common relationship finds concrete expression in the different by their nature economic phenomena and processes.

In order to understand the core, it is obvious that it is necessary to proceed from the fundamental postulate that the negative developments in the financial relationships are dangerous, causing damage to the real economy, which is reflected in the falling rate of development, reducing the living standards of the population. In this regard, the financial threats should be considered, in our opinion, as a factor that creates a hazard, causing damage to the financial system and destroys it as a system. And it all can't be attributed to the possible objectively existing negative factors affecting financial and market relations (Cooper R.N., 2015).

The growing danger, accompanied by an increase in the damage, of course, leads to a transition of quantity into a new quality - to the threat.

Scope of a safe existence is so narrowed that has a stagnating effect on the functioning and development of the economy. Practically, as a security it's understood such economic conditions, which means that the probability of an unwanted change of any of its properties to the level not above or below the certain limit.

Practically, in the economic literature there is no systematic definition of "financial security", which makes it necessary to solve this problem. Thus, one of the most important aspects of the problem of economic security of the state - the state of its financial system (the state budget and other institutions), the ability of this system to provide state financial resources sufficient to fulfill its internal and external functions.

The financial system has to have a certain margin of safety in case of unforeseen and extraordinary circumstances, so that the public authorities are able to respond quickly and timely to the any emergence threats and possibly prevent them, neutralize, or at least to minimize the potential socio-economic losses.

We can distinguish the following basic segments of the financial security of the country and regions:

- The budget and tax;

- Monetary;

- Credit and banking;

- Extra-budgetary fund.

Materials and Methods. Conceptually, the formation of an effective system of financial security should be based on the creation of complex monitoring, layered and full-scale system for tracking the dynamics of all major financial and economic processes in the country. The obvious challenge is to develop precise criteria and financial security levels.

Complex of the factors relating to internal and external conditions of the enterprise has an impact on the dynamics of financial performance affects.

In countries with the advanced economy, the financial failure of companies is for $1 / 3$ determined by external factors and for $2 / 3$ - internal (of course, this is the average expert assessment). In developing countries and countries with economies in transition financial negatives are more dependent on the external environment influence (general economic crisis, inflation, payments crisis, the banking sector, etc.) (Piketty Th., 2014).

Understanding the financial security as the object of research should be based on an understanding the nature of the financial system, not limited only by its distribution and redistribution functions, and accumulation of financial resources. As a system, it includes the specific characteristics of financial instruments, reflecting to some extent the nature of ownership, and a set of relations of the property and financial instruments characteristics forms both capital flows, and their distribution, as part of the monetary and fiscal policy. The transition to a market economy has led to strengthening of the role of finance and determined their place in the new economic system.

The global financial market is not the market of the original capital period, as its main participants are the largest financial-industrial conglomerates and international financial centers, weakens the mechanism of the average rate of profit, changes income distribution scheme, many basic categories change their content. 
Hitherto, there has formed a huge gap between the tangible and financial flows: "financial economy somewhere in twenty, if not fifty, times more than the real economy." One can argue about the legitimacy of such an idea, especially in terms of the state of the financial and the real economy, but the reality is that the financial market growth is many times greater than the volume of trade in goods and services, in particular, currency exchanges turnover in the order of more than trade in goods.

Analyzing the genesis of finance, we can note that it's the result of evaluation of social processes and has a technological origin. Finances as resources of the subjects have a long historical path of development as means of assessment and the importance of the subjects' resources or the volume of losses. They are not only the world of ratings and comparisons, but also a specific form of activity, based on knowledge of the financial "being" and developing itself. It's kind of financial production with its technology, resources, laws, form of objective reality.

Finances as a major online subjects' resource exist in several forms. Firstly, finance, serving the real economy, is its reflection. There is a fairly clear connection between them, well studied and presented by economic sciences, theories and laws.

Secondly, finances exist as a separate and independent form of action, functioning on the basis of its own in accordance with its laws, tools, technology, unique to it. This activity aims to increase the financial resources (capital) by own methods, often without any direct connection with the real economy. This type of financial activity is called speculative activity, generating fictitious financial resources. On this kind of activity, quite legitimate, parasitize both citizens and a variety of organizations, from small businesses to multinational corporations, as well as the state, that produces the threats of all sizes.

Thirdly, finances exist as a branch of knowledge, as a science. It generates advanced financial technology, diverse and sophisticated financial instruments that allow $\mathrm{s}$ the more efficient use of existing financial resources and ways to accelerate the production of new ones.

Nature of the financial resources, their main characteristic is that they are formed in the manufacturing development process, improvement of its competitiveness and marketability. The vast majority of financial resources is generated in the production process and the use of real wealth, as well as in the service sector. The real sector of the economy not only consumes financial and banking resources, but also creates them. Art of the financial and economic policy is reduced to finding the initial foundations for the resumption of economic growth. Great is the role of the production in providing the necessary productive employment and increasing incomes of the population that are the basis of savings of the population, development of securities market and thus increasing the financial potential for savings and investment. Unfortunately, forgetting these postulates is the basis of exacerbation of financial risks of development of society.

As noted earlier, the concept of financial security, firstly, should correspond with the general concept of national security; secondly, perform an integral part of the concept of economic security of the country; and thirdly, have its own content, which distinguishes the problems of financial security from the same kind of general economic problems.

Indicators of the financial security. Financial indicators of economic security can be divided into the following criteria:

- macro-;

- price;

- reflecting the process and the state of the financial markets;

- related to banking activity;

- reflecting the level of savings and investment in the economy;

- related to the foreign exchange market and the exchange rate of the national currency.

To complete the picture of the processes occurring in the financial sector of the economy, it is necessary to analyze the indicators over time and compare them with the threshold values of economic (financial) security. Violation of this or that indicator itself doesn't mean a threat to the economic security in general. But the organization of monitoring, comprehensive review of the system of indicators, an in-depth analysis of individual economic entities and processes at a deviation from the normal criteria of the dynamics of the trajectory should be object to continuous monitoring of the competent public authorities.

Ratio analysis of financial security in Central Asia. For the analysis there were selected the following countries of central and eastern Asia, the countries - members of the Shanghai Cooperation Organization: Russia, Kazakhstan and China. 
As for Russia, the results of applying the methodology of quantitative analysis are provided in Appendix B.1, (Gaidar E.T., 2014) which shows the values that were accepted by indicatorsprecursors of financial instability in the III quarter 2013 - I quarter 2014, the threshold levels of the indicators, and also reflects the fact, whether they set signal or not. (Gaidar E.T., 2013).

Appendix 1. Status of the system of indicators-harbingers of financial instability in the III quarter 2013 - I quarter 2014 in the Russian Federation

\begin{tabular}{|c|c|c|c|c|c|c|c|}
\hline \multirow[b]{2}{*}{ Indicator } & \multirow[b]{2}{*}{$\begin{array}{l}\text { The } \\
\text { threshold }\end{array}$} & \multicolumn{2}{|c|}{ III quarter 2013} & \multicolumn{2}{|c|}{ IV quarter 2013} & \multicolumn{2}{|c|}{ I quarter 2014} \\
\hline & & $\begin{array}{l}\text { The value } \\
\text { of the } \\
\text { indicator }\end{array}$ & Signal & $\begin{array}{l}\text { The value } \\
\text { of the } \\
\text { indicator }\end{array}$ & Signal & $\begin{array}{l}\text { The value } \\
\text { of the } \\
\text { indicator }\end{array}$ & Signal \\
\hline $\begin{array}{l}\text { The balance of the } \\
\text { current account payment } \\
\text { balance }\end{array}$ & $\begin{array}{l}-1,5 \\
\text { billion. dol. }\end{array}$ & $\begin{array}{l}15,7 \\
\text { billion. } \\
\text { dollars }\end{array}$ & 0 & $\begin{array}{l}16,3 \\
\text { billion. } \\
\text { dollars }\end{array}$ & 0 & $\begin{array}{l}33,9 \\
\text { billion. } \\
\text { dollars }\end{array}$ & 0 \\
\hline $\begin{array}{l}\text { The real interest rate on } \\
\text { the interbank market }\end{array}$ & $4,4 \%$ & $0,6 \%$ & 0 & $0,0 \%$ & 0 & $-0,3 \%$ & 0 \\
\hline $\begin{array}{l}\text { The ratio of money } \\
\text { supply to gold reserves }\end{array}$ & 3,7 & 1,1 & 0 & 1,2 & 0 & 1,2 & 0 \\
\hline $\begin{array}{l}\text { The real effective } \\
\text { exchange rate of ruble }\end{array}$ & $+6,5 \%$ & $+1,2 \%$ & 0 & $-1,8 \%$ & 0 & $+2,4 \%$ & 0 \\
\hline $\begin{array}{l}\text { "Excessive" money } \\
\text { supply in real terms }\end{array}$ & $2,2 \%$ GDP & $\begin{array}{l}0,6 \% \\
\text { GDP }\end{array}$ & 0 & \begin{tabular}{|l|}
$4,7 \%$ \\
GDP \\
\end{tabular} & 1 & $7 \%$ GDP & 1 \\
\hline $\begin{array}{l}\text { The spread between } \\
\text { domestic interest rates } \\
\text { and the rate of LIBOR }\end{array}$ & 40 p.p. & 6,98 p.p. & 0 & 4,92 p.p. & 0 & 3,4 p.p. & 0 \\
\hline GDP Growth rate & $-5,2 \%$ & $-7,7 \%$ & 1 & $-3,8 \%$ & 0 & $4,5 \%$ & 0 \\
\hline $\begin{array}{l}\text { The trade conditions (the } \\
\text { price of oil brand } \\
\text { "Brent") }\end{array}$ & $\begin{array}{l}12,1 \text { dol. } \\
\text { per barrel }\end{array}$ & $\begin{array}{l}68,9 \text { dol. } \\
\text { per } \\
\text { barrel }\end{array}$ & 0 & $\begin{array}{l}77,9 \text { dol. } \\
\text { per } \\
\text { barrel }\end{array}$ & 0 & $\begin{array}{l}82,5 \text { dol. } \\
\text { per } \\
\text { barrel }\end{array}$ & 0 \\
\hline Capital outflow & $\begin{array}{l}-8,3 \\
\text { billion. dol. }\end{array}$ & $\begin{array}{l}-\quad 5,2 \\
\text { billion. } \\
\text { dollars }\end{array}$ & 0 & $\begin{array}{l}-\quad 4,9 \\
\text { billion. } \\
\text { dollars }\end{array}$ & 0 & $\begin{array}{l}-17,3 \\
\text { billion. } \\
\text { dollars }\end{array}$ & 1 \\
\hline Gold reserves & $-2,2 \%$ & $+0,9 \%$ & 0 & $-2 \%$ & 0 & $2,5 \%$ & 0 \\
\hline Export & $-5,7 \%$ & $-34,3 \%$ & 1 & $19,7 \%$ & 0 & $58,1 \%$ & 0 \\
\hline Domestic credit & $1,6 \%$ & $+3,5 \%$ & 1 & $+12,4 \%$ & 1 & $+0,8 \%$ & 0 \\
\hline $\begin{array}{l}\text { Pressure index on the } \\
\text { currency market }\end{array}$ & 1,7 & $-0,8$ & 0 & 2,2 & 1 & $-0,7$ & 0 \\
\hline
\end{tabular}

Appendix 2. The probability of the Russian financial instability

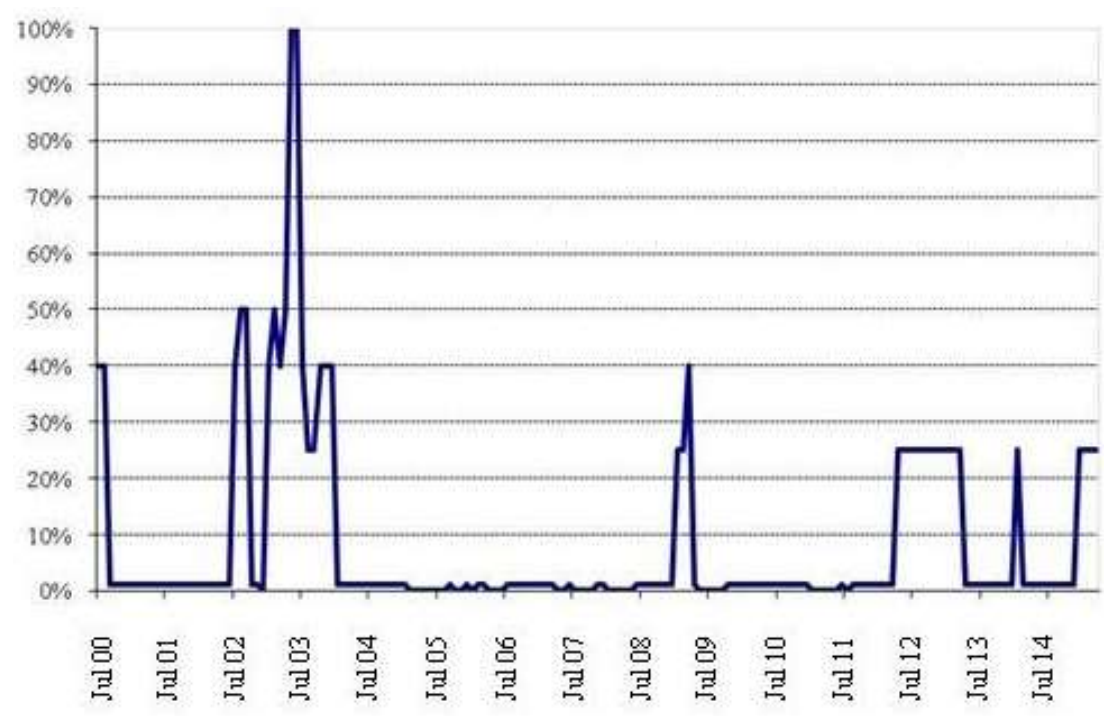


In a quarter of 2013, the financial system of the Russian Federation continued to grow quite steadily. At the same time, some problems in the financial sector of the country still occurred, which was connected primarily with concerns about the development of the situation with the debt of Greece and some other European countries. In I quarter of 2014, only two of the thirteen indicators set signal - the capital outflow and "excessive" money supply in real terms.

Significant acceleration of capital outflow at the year's beginning may mean that on the background of continuing high risks and, at the same time, a high level of liquidity in the financial system, the Russian economic agents preferred to withdraw money abroad. This trend, of course, is negative and reflects the low confidence of Russian economic agents in the further economic development stability. In addition, the fixed amount of "excess" money supply indicates that in the short term, inflation in Russia may accelerate again.

Fixed state of the system of indicators-harbingers corresponds to the probability of increasing the scale of financial instability for the next one to two quarters, at around $20-25 \%$. This result suggests that in the next three - five months of 2010 there is the likelihood of some of the problems in the financial sector of the Russian Federation. (Gaidar E.T., 2014

Indicators of financial security of the Republic Kazakhstan are given in Appendix B.3 (The main socio-economic indicators, 2013; World Development Indicators \& Global Development Finance, 2015).

Appendix 3. Indicators of Kazakhstan's financial security

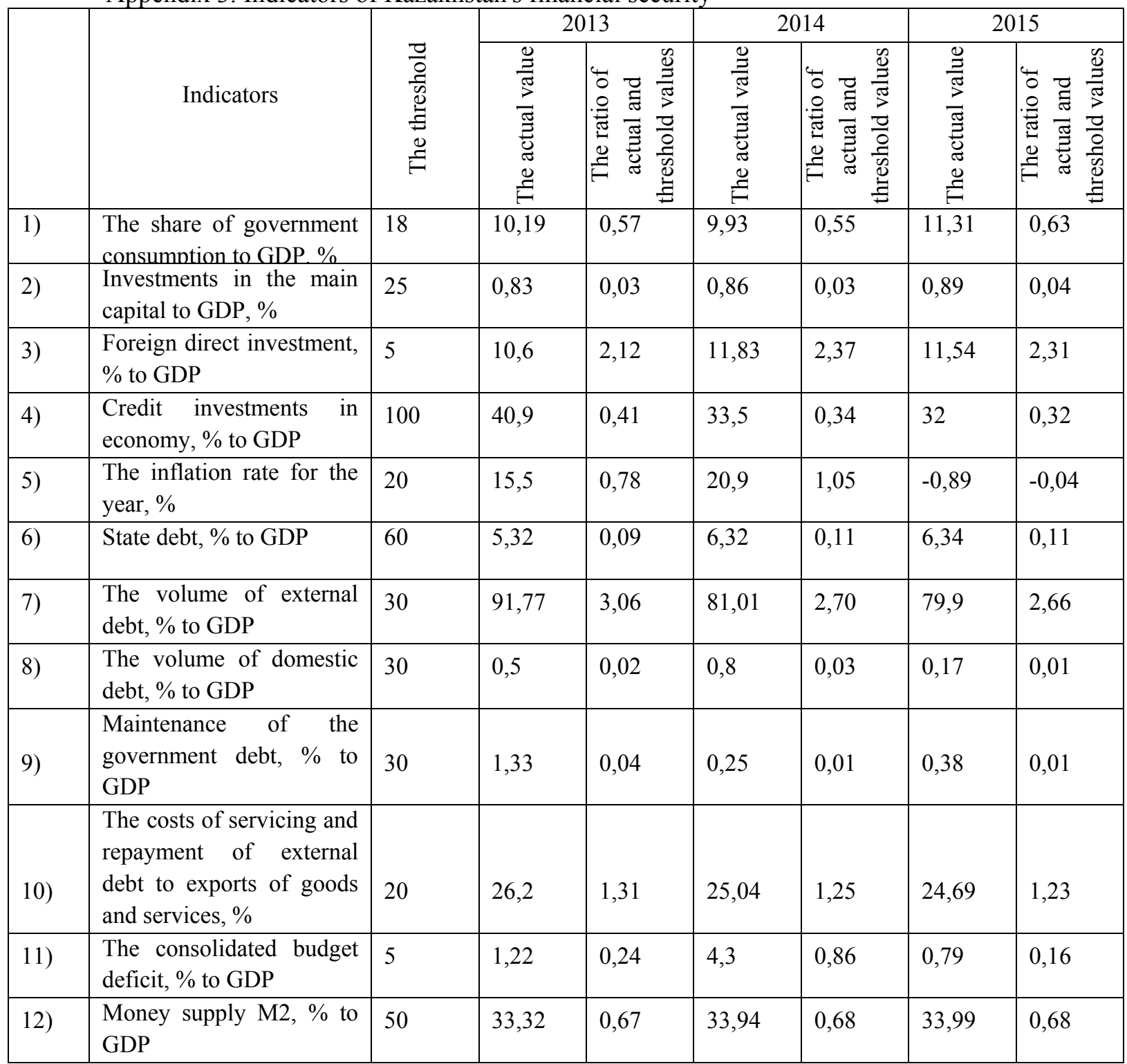


The results of this year proved the adequacy of estimates. The situation in 2009 showed that a combination of different risk factors may have a significant destabilizing character and require the state large-scale financial and regulatory intervention in order to maintain financial stability.

In particular, as a result of the decline in world prices and the devaluation of the currencies of countries - major trade partners of Kazakhstan significantly worsened the parameters of the real effective exchange rate of KZT, increased scale of slowdown in economic activity, significantly reduced foreign exchange inflows from exports. As a result, a composite indicator that shows the degree of vulnerability of the economy to foreign exchange crisis and is calculated based on a set of economic indicators of financial and macroeconomic stability, has exceeded the threshold already in November 2014, which indicated an increase in the likelihood of significant pressure on the currency market in the short term.

Devaluation of the national currency in February 2014 and the selected by the National Bank priorities of monetary policy allowed to repay the speculative expectations of the market, partly compensated the loss of business from the unfavorable price situation on world commodity markets and limited the expansion of the imbalances of the payment balance. The subsequent rise in world commodity prices further supported the export-oriented sectors of the economy, which in the 2nd half of the year show the dynamics of output recovery and improved financial performance.

According to the results of 9 months of 2014, it should be noted that the pure outflow of deposits from the system, which could be the most undesirable result of devaluation and measures on stabilizing the banking system, has not happened. In contrast, household deposits rose by more than $20 \%$. In this case, the outflow of depositors was observed by individual banks rather than from the general banking system. In particular, considering the average level of redistribution of deposits between banks at $4-5 \%$ within 2 years, in the 1 st and 2 nd quarters of 2014 , about $8-11 \%$ of deposits have migrated inside the banking system in search of a safe haven or a more attractive environment.

Slowing economic growth and domestic demand had the most significant impact on small business industries oriented to the domestic consumer goods and services. In particular, the increasing number of non-performing and non-active businesses may carry a risk of growth of bankruptcies, if economic growth recovery database does not expand at the expense of non-primary sectors of the economy.

Despite the marked decline in terms of financial stability, the level of external debt of the banking sector remains high. Only the availability of reliable and stable domestic funding of sources can further contribute to painless reduction of volumes of external financing banks.

Measures of macro-prudential regulation should be focused on the stability of the financial system as a whole, on the prevention of the accumulation of imbalances and rising systemic risk, and synchronized with the objectives of monetary and fiscal policy measures and micro-prudential regulation. Within the framework of micro-prudential regulation, the focus is on an adequate assessment, risk control and quality management systems in banks. This control system should withstand the optimal balance between tightening the requirements for financial institutions and the preservation of opportunities for diversification of sources of profit.

In general, the maximum efficiency of macro-prudential regulation can be achieved only if it is carried out as an integral part of the overall macroeconomic policy. To this end, there was strengthened the role of the National Bank as the central body responsible for ensuring financial stability and the implementation of macro-prudential regulation. (Financial Stability Report of Kazakhstan, 2009)

In the fourth quarter of 2009 , the situation on the financial markets remained calm in Kazakhstan. The only unfavorable trend was the reduction of deposits in real terms against the background of stagnation in lending the real sector of the economy. Overall, the significant dependence of Kazakhstan's economy from the external economic environment is likely to lead to a slow recovery of the economy in case of deepening of the new challenges in the global economy. (Gaidar E.T., 2014)

According to the selected indicators, which provide the country's financial security (see. Appendix B.4) (World Development Indicators \& Global Development Finance, 2015; World Economic Outlook Database, 2014), in China there is a stable situation, all indicators are normal. However, there is a tendency to lower credit injections into the economy. 
Appendix 4. Indicators of China's financial security

\begin{tabular}{|c|c|c|c|c|c|c|c|c|}
\hline \multirow{2}{*}{\multicolumn{2}{|c|}{ Indicators }} & \multirow[b]{2}{*}{ 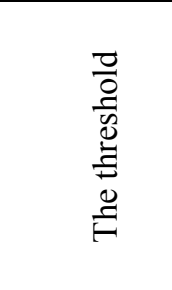 } & \multicolumn{2}{|c|}{2013} & \multicolumn{2}{|c|}{2014} & \multicolumn{2}{|c|}{2015} \\
\hline & & & 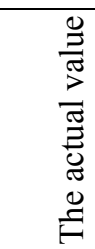 & 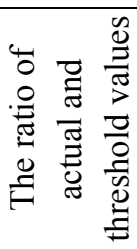 & 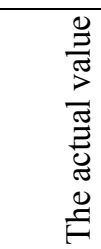 & 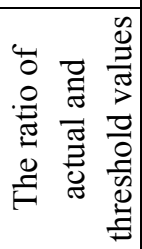 & 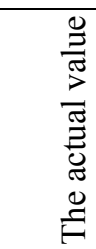 & 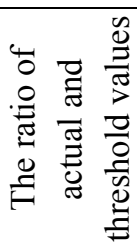 \\
\hline 1) & $\begin{array}{l}\text { The share of government } \\
\text { consumption to GDP, } \%\end{array}$ & no more 18 & 13,2 & 0,74 & 13 & 0,72 & 11,49 & 0,64 \\
\hline 2) & $\begin{array}{l}\text { Investments in the main } \\
\text { capital to GDP, } \%\end{array}$ & no less 25 & 29 & 1,16 & 32 & 1,28 & 30 & 1,2 \\
\hline 3) & $\begin{array}{l}\text { Foreign } \\
\text { investment, } \% \text { to GDP }\end{array}$ & no less 5 & 10,6 & 2,12 & 12 & 2,37 & 11,54 & 2,31 \\
\hline 4) & $\begin{array}{l}\text { Credit investments in } \\
\text { economy, \% to GDP }\end{array}$ & no less 100 & 150 & 1,50 & 119 & 1,19 & 109 & 1,09 \\
\hline 5) & $\begin{array}{l}\text { The inflation rate for the } \\
\text { year, } \%\end{array}$ & no more 20 & 7,6 & 0,38 & 7,8 & 0,39 & $-0,61$ & $-0,03$ \\
\hline 6) & State debt, $\%$ toGDP & no more 60 & 19,8 & 0,33 & 17 & 0,28 & 18,6 & 0,31 \\
\hline 7) & $\begin{array}{l}\text { The volume of external } \\
\text { debt, } \% \text { to GDP }\end{array}$ & no more 30 & 11 & 0,37 & 8,7 & 0,29 & 8,69 & 0,29 \\
\hline 8) & $\begin{array}{l}\text { The volume of domestic } \\
\text { debt, } \% \text { to GDP }\end{array}$ & no more 30 & $-0,39$ & $-0,01$ & 0,9 & 0,03 & $-2,9$ & $-0,10$ \\
\hline 9) & $\begin{array}{l}\text { Maintenance of the } \\
\text { government debt, } \% \text { to GDP }\end{array}$ & no more 30 & 0,79 & 0,03 & 0,6 & 0,02 & 0,63 & 0,02 \\
\hline 10) & $\begin{array}{l}\text { The costs of servicing } \\
\text { and repayment of } \\
\text { external debt to exports } \\
\text { of goods and services, } \%\end{array}$ & no more 20 & 0,75 & 0,04 & 0,9 & 0,05 & 0,96 & 0,05 \\
\hline 11) & $\begin{array}{l}\text { The consolidated budget } \\
\text { deficit, } \% \text { to GDP }\end{array}$ & no more 5 & 4 & 0,80 & 4 & 0,80 & 3 & 0,60 \\
\hline 12) & $\begin{array}{l}\text { Money supply M2, \% to } \\
\text { GDP }\end{array}$ & no less 50 & 141 & 2,82 & 140 & 2,80 & 159,3 & 3,19 \\
\hline
\end{tabular}

In 2009 the activities of the financial market in China was carried out in a safe manner, there was a brisk trade and progressive institutional reconstruction, which contributed to the effectiveness of macroeconomic policies, it has played the role of maintaining financial stability and strengthening the financial support for economic development fully.

The volume of money market showed significant growth. In 2009, trading on the money market was quite lively. The turnover of inter-bank loans grew by $28.6 \%-19,4$ trillion yuans. Turnover debt reached 70.3 trillion. yuans, which corresponds to $20.9 \%$. This significant growth was mainly contributed through the maintenance of liquidity and low interest rates in the money market, which made it possible to lower the cost of funds, and thus encourage high trade requirements.

Short-term operations accounted a significant proportion of the total turnover. In 2009, the turnover of the night on the interbank borrowing has reached 16, 2 trillion. yuans, accounting for $83.5 \%$ of total interbank loans, an increase of $13 \%$. (China Financial Stability Report, 2010) Shortterm transactions dominated the market as money market played a prominent role in adjusting the liquidity of financial institutions.

Evaluation and efficiency of the financial market in Central Asia.

Financial markets are a key component of the national economy. Effectively operating financial markets are designed (along with a developed banking system) to accumulate savings of economic agents, to transform them into investments and ensure their distribution among the various sectors of the economy. In addition, developed financial markets contribute to the inflow of foreign investment (especially portfolio), the amount of which depends substantially on the level of current interest rates, the risks of various kinds, and their transformation into investments is determined by the economic fundamentals of the country, carried out by fiscal and monetary policy, social and political risks, and such aggregated measures as investment risks.

By directions of increase of efficiency of financial markets in China include: firstly, it is strengthening the growth prospects based on structural reforms. This means the artificial, often local 
intervention in economic structures in order to coordinate and regulate the activities of various organizations. Such work requires constant monitoring of the labor market and the financial markets, the identification of "tense" places and stimulation of development in one way or another. The aim is a healthy and qualitative "fruition" of the economy and employment.

Secondly, it is fiscal consolidation to ensure the sustainability of the economy. However, it is quite possible scenario in which, on the short-term, realization after asset consolidation programs will be connected with such problems.

The third element is a state monetary policy aimed at price stability. This includes all variety of measures to regulate money circulation.

Finally, the fourth element, included in the proposed set of economic measures, is the financial stability and security. "To create a secure financial system, the responsible authorities should ensure all sectors of the economy, at both the micro- and macro-level. The main task for policy makers will be to develop appropriate measures for enhancing the stability of the financial system without any restrictions that could hinder innovation or reduce the effectiveness of the system." This means a comprehensive reorganization of financial institutions in a direction similar to the direction in which the US economy moved last year. Financial Security is the transparency of the system, is stricter and clear rules, strict accountability, creating new supervisory agencies.

Generally, in the post-crisis period, a lot of suggestions were made to establish new secure and stable economic structures. In China, such programs are being implemented quite successfully - in different ways. (Financial security at the international level, 2015)

For example, November 5, 2008 Meeting of the State Council discussed methods for increasing economic growth and reducing the country's dependence on financial crises. According to this plan, the Chinese government needs to invest 1.18 trillion yuans to the end of 2010 , what should be a lever for private investors, and according to expectations it should stimulate investments worth 4 trillion yuans (China Financial Stability Report, 2010).

In 2009, the government of China formed stimulating reform package, covering four main areas: a vast public investment, regulation and widespread revival of the industry, powerful technology support and increase security measures. (Balance Sheet. Finance., 2016) There're also used the new programs on risk management. Since 2006 China is preparing to join the Financial Sector Assessment Program (FSAP), the process should be finished in July 2011, what will have a positive impact on the financial security of the maintenance of the country.

Conclusions. Practically, there's no aspect of the national security of the country that wouldn't directly dependent on the level of its financial security. At the same time, the level of the financial security largely depends on the level of other aspects of national security. Consideration of the relationships and interdependencies between the various aspects of national security allows finding measures to prevent or overcome threats to the country's national interests.

The dependence of all aspects of the national security of the country on its financial security is very simple at the first glance: lack of funds often leads to underfunding the most pressing needs in the various sectors of the economy and poses a threat to national security. However, this seemingly simple, the most common relationship finds concrete expression in the different by their nature economic phenomena and processes.

There is an inverse relationship between the financial security of the country and its general national security. It is important to consider the close relationship of various aspects of the country's national security and a key role of the financial security in overcoming threats to national interests.

That is why the economy is now facing the problem of developing such a new course, the most important element of which is a financial security strategy that requires a consistent practice of purposeful work aimed at reviving the economy and the resumption of growth. It means that the system of the financial security involves not only the efficient functioning of the financial system itself, but also the safe operation of all elements of the financial and economic mechanism of the country.

In the market economy, changes of financial parameters lead to a sharp change in the money supply and demand in the economy and, consequently, has a powerful impact on the dynamics of economic development in general. Therefore, financial analysis and forecasting of economic criteria and safety indicators have the fundamental importance. Moreover, financial security indicators are key indicators of potential economic distress in the country. Financial indicators of economic security can be divided into the following criteria: macro-; price; reflecting the processes and the state of the financial markets; related to banking activity; reflecting the level of savings and investment in the economy; related to the foreign exchange market and the exchange rate of the national currency.

For the analysis there were selected the following countries of central and eastern Asia, the countries - members of the Shanghai Cooperation Organization: Russia, Kazakhstan and China. 
In 2009, the financial system of the Russian Federation continued to grow quite steadily. At the same time, some problems in the financial sector of the country are still occurred, which was primarily connected with concerns about the development of the situation with the debt of Greece and some other European countries.

Fixed state of the system of indicators-harbingers corresponds to the probability of increasing the scale of financial instability for the next one to two quarters, at around $20-25 \%$. This result suggests that in the next three - five months of 2010 there is the likelihood of some of the problems in the financial sector of the Russian Federation.

In 2009 , the situation in the financial market of Kazakhstan also remained calm. The only unfavorable trend was the reduction of deposits in real terms against the background of stagnation in lending to the real sector of the economy. Overall, the significant dependence of Kazakhstan's economy on the external economic environment is likely to lead to a slow recovery of the economy in case of deepening of the new challenges in the global economy.

In China, there is a stable situation, all indicators are normal. However, there is a tendency to decrease of credit injections into the economy. In 2009, activity on the financial market was carried out in a safe manner, there was a brisk trade and progressive institutional reconstruction, which contributed to the effectiveness of macroeconomic policies, and played the role of maintaining financial stability and strengthening the financial support for economic development fully.

In order to ensure the financial security of Russia there should be solved the following objectives: ensuring the stability of the financial system by optimizing the budget and tax of the federal government policy, minimizing dependence of regions on the federal budget, the normalization of financial flows, the stability of the banking system, reducing external and internal debt and providing financial conditions for activation of investment and innovation.

To improve the efficiency of the financial market there can be offered technical innovations in the provision of full and accessible information in the functioning of the financial market, which will make transparent the activities of market participants.

\section{REFERENCES}

1. Drobozinskaya L.A. (2000). Finance. Money treatment. Credit - M.: UNITY, P.62.

2. Bogomolov V.A. (2009). Economic security: Textbook. Allowance for students studying in the field of economics and management / 2 nd ed., Revised. And add. - M.: UNITY-DANA, 2009 - 295, S. 176.

3. Korsuntsev I. (1999). Virtual Finance / / I.G. - Political Economy. № 16. November 2nd.

4. Gaidar E.T. (2014). Monitoring of financial stability in Russia, countries with economies in transition and developing countries (I quarter 2014). Institute for Economic Policy.

5. World Development Indicators \& Global Development Finance (2015). World Data Bank. Available at: http://databank.worldbank.org/ddp/exportData

6. World Economic Outlook Database (2014). International Monetary Fund.

7. China Financial Stability Report (2010). The People's Bank of China.Available at: http://www.pbc.gov.cn/publish/english/3060/index.html

8. Azhihanov S.O. (2014). The functioning of the banking system of the Republic of Kazakhstan in terms of economic reforms // Proceedings of the international scientific-practical conference. Almaty. pp.-250-253

9. Financial security (2013). Kazakhstan's news aggregator. Available at: http://henews.kz/2010/05/31/383641.html

10. Financial security at the international level (2015). A financial rating. Information portal. Available at: http://financial-rating.ru/news/theme-of-the-day/1288/

11. Balance Sheet. Finance. (2016). - Available at: http://finance.yahoo.com/q/bs?s=CSR+Balance+Sheet\&annual

12. Main socio-economic indexes of Kazakhstan. (2011-2015). Statistical year-book. Astana: The Agency of RK for statistics.

13. Official statistical information 'Investments' (2016). Kyzylorda: The Committee for statistics of the Ministry of National Economy of the Republic of Kazakhstan. Available at: http://stat.gov.kz/faces/wcnav externalId/publicationsPage?_afrLoop=31921278309053839\#\%40\%3F_afrLoop\%3D31921278309053839\%26_adf.ctrlstate\%3Dk3aljbtty_177

14. Report on the financial stability of Kazakhstan (2011-2015). Almaty: NBK. 278. Available at: http://www.nationalbank.kz

15. World Economic and Social Survey (2013): Sustainable Development Challenges. Available at: http://www.un.org/en/development/desa/publications/world-economic-and-social-survey-2013-sustainabledevelopment-challenges.html

16. Mian A., Sufi A. (2015). House of Debt: How They (and You) Caused the Great Recession, and HowWe Can Prevent it from Happening Again. - Chicago

17. Piketty Th. (2014). Capital in the Twenty-First Century, translated by Arthur Goldhammer, Harvard,2014

18. Tsygankov A.P. (December 16, 2014). The Strong State in Russia: Development and Crisis. - Oxford University Press

19. Cooper R.N. (2015). Other People's Money: The Real Business of Finance 